\title{
Dysnatremia in ICU elderly patients: prevalence and outcome
}

\author{
Mohamed G. Zakaria, 1 Mohamad A. Alsadany1, Mohamed H. El-Banouby1. Abeer H. M. Matter 1
}

1Department of Geriatric Medicine, Faculty of Medicine, Ain Shams University.

\section{Abstract}

Background: Dysnatremia is the most common electrolyte disorder in elderly ICU patients; encompassing both hyponatremic and hypernatremic conditions. Dysnatremia has been associated with adverse outcome in ICU.

Aim: to detect the prevalence of dysnatremia in older ICU patients, and also to evaluate association between dysnatremia and in-hospital mortality in the Geriatrics Intensive Care Unit.

Subjects and Methods: A cross sectional observational study for 120 elderly ICU patients, studying prevalence of hyponatremia and hypernatremia during their ICU admission and its relation to ICU mortality.

Results: Hyponatremia is commoner than hypernatremia (42.5\% Vs $10.83 \%$ ). Mild, moderate, severe hyponatremia was $(24.2 \%, 13.3 \%, 6 \%$ respectively). Mild, moderate, severe hypernatremia was $(7.5 \%, 3.3 \%, 0 \%$ respectively). Total in-hospital mortality for all ICU patients was $60 \%, 45.83 \%$ of non-survivors had hyponatremia that ranged between mild $(26.39 \%)$, moderate $(13.89 \%)$ or severe $(5.56 \%)$, while $9.72 \%$ of non-survivors had hypernatremia either mild $(6.94 \%)$ or moderate $(2.78 \%)$ hypernatremia.

Conclusion: Prevalence of dysnatremia was high in ICU elderly patients. Hyponatremia was found more frequent than hypernatremia. Mild form of dysnatremia is the most prevalent type in both groups.

Keywords: Dysnatremia, elderly, ICU, mortality.

\section{Background}

Dysnatremia is the most common electrolyte disorder in hospitalized patients. It encompasses hyponatremic and hypernatremic conditions. It is a common finding at Intensive Care Unit (ICU) admission [1-3]. Nearly one third of critically ill patients have dysnatremia at ICU admission [2].

Hyponatremia is a pathologic condition defined as a serum sodium $<135 \mathrm{mmol} / \mathrm{L}$. It is the most common electrolyte disorder in hospitalized patients. Up to $40 \%$ of the overall hospitalized patients have a hyponatremia at admission [4]. Presence of severe hyponatremia on hospital admission has been demonstrated to be independently associated with an increased risk for ICU admission and poor prognosis [5]. Hyponatremia may be due to chronic organ dysfunctions (that is heart failure or liver dysfunction), diuretic use, syndrome of inappropriate antidiuretic hormone (ADH) secretion, adrenal insufficiency, and cerebral or renal salt wasting syndromes. Hyponatremia is often a marker of severity of underlying disease [6,7].
In addition to critical illness per se, factors contributing to hyponatremia in ICU include excess use of hypotonic fluids and drugs stimulating antidiuretic hormone secretion [8].

Hypernatremia is defined as a serum sodium > 145 $\mathrm{mmol} / \mathrm{L}$. It is generally related to excess water losses with increase of plasma osmolality. Serum sodium is the main cation of extracellular fluid and plays a key role in serum osmolarity. Hypernatremia is less frequent than hyponatremia [6], with a reported inhospital prevalence of up to $7.7 \%$ [2]. Since thirst and free access to water are the most important mechanisms that prevent hypernatremia, critically ill patients and older patients are at high risk for this disorder [7,9].

Since hypernatremia is often iatrogenic, hypernatremia acquired in the ICU has been considered as an important index of quality of care [10]. Only $2.5 \%$ patients have been found to develop moderate to severe hypernatremia in general in-hospital population of patients. Higher prevalence has been reported in 
geriatric or critically ill patients [11-14]. Hypernatremia has multiple adverse effects on physiologic functions, which may explain its association with increased mortality. Hypernatremia aggravates peripheral insulin resistance [15], impairs hepatic gluconeogenesis and lactate clearance $[16,17]$, and decreases left ventricular contractility [18]. Additionally, hypernatremia is associated with various neuromuscular manifestations, such muscle weakness and cramps [19]. Neurologic impairment remains the most severe consequence of hypernatremia and may prolong the need for mechanical ventilation and delay weaning [20]. Finally, too rapid correction of chronic hypernatremia can cause cerebral edema [20].

\section{Methods}

The present study is a cross-sectional observational study done over 6 months (January 2019 till July 2019) to detect prevalence of dysnatremia in elderly ICU patients, and to evaluate association, if any, between grades of dysnatremia and in-hospital mortality in critically ill elderly patients admitted to the Geriatric ICU, Ain -Shams University Hospitals.

The study was performed in adherence to the principles established with the Declaration of Helsinki and the study methodology was reviewed and approved by the Research Review Board of the Geriatrics and Gerontology Department, Faculty of Medicine, Ain Shams University.

\section{Exclusion criteria}

1. Patients who are less than 60 years' old

2. Patients stay less than 48 hours at ICU.

Study tools: All patients were evaluated by history and clinical examination.

Serum sodium (s. Na) level was measured for all participants during their admission in intensive care. Based on s. Na level patients were classified into mild (130-134 mg/dl), moderate (125-129 mg/dl) and severe hyponatremia (<125 mg/dl), normal subjects (135-145 $\mathrm{mg} / \mathrm{dl}$ ), mild hypernatremia (146-149 mg/dl), moderate hypernatremia (150-159 mg/dl), severe hypernatremia $(\geq 160 \mathrm{mg} / \mathrm{dl})$.

Statistical analysis: The statistical analysis of the research was performed with the SPSS 22.0 package program. Descriptive statistics were carried out for all variables and expressed as mean and $\pm \mathrm{SD}$ for quantitative data, whereas qualitative data were expressed as numbers and percentages. Comparisons between means were made with the Student's t test. Distributions were compared with the Chi-square test. A $p$ value $<0.05$ was considered statistically significant.

\section{Results}

Table (1) showed that 120 patients were recruited for the study, with a mean age of $74.075 \pm 8.852$ years, $71.67 \%$ were between the age of 60 and 79 , while patients 80 or older were $28.33 \%$ of all admitted patients. women were the majority of admitted patients $(73.33 \%)$. The majority of the admitted elderly were widowed $(56.67 \%)$, and the majority of the admitted patients $(93.33 \%)$ were idle (those that never worked or retired).

Table 1: Demographics of elderly patients admitted to the ICU.

\begin{tabular}{lcll}
\hline \multirow{2}{*}{ Age } & Range & \multicolumn{2}{l}{$\mathbf{6 0 - 9 6}$} \\
\cline { 2 - 4 } & Mean \pm SD & \multicolumn{2}{l}{$\mathbf{7 4 . 0 7 5 \pm 8 . 8 5 2}$} \\
\cline { 2 - 4 } Age group & $<\mathbf{8 0}$ Years & 86 & 71.67 \\
& $>\mathbf{8 0}$ Years & 34 & 28.33 \\
Gender & Male & 32 & 26.67 \\
\multirow{2}{*}{ Marital } & Female & 88 & 73.33 \\
state & Single & 5 & 4.17 \\
& Married & 47 & 39.17 \\
Occupation & Wctive & 68 & 56.67 \\
& Retired & 8 & 6.67 \\
& Housewife & 85 & 22.50 \\
\hline
\end{tabular}

Table (2) showed that $42.5 \%$ of elderly ICU experienced hyponatremia with its stages (mild, moderate, severe hyponatremia) were $(24.2 \%, 13.3 \%$, and $6 \%$ respectively). Hyponatremia was found to happen more in certain medical conditions as diabetes mellitus (25.8\% Vs 18.3\%), heart failure (14.17Vs $13.3 \%)$ and liver cell failure (10\% Vs $7.5 \%)$, although this was statistically non-significant.

Hypernatremia was found in $10.83 \%$ of elderly ICU patients with its stages (mild, moderate, severe hypernatremia) were $(7.5 \%, 3.3 \%, 0 \%$ respectively). Regarding co-morbidities, hypertension was the most prevalent medical condition found in all ICU patients $(57.5 \%)$, followed by diabetes mellitus $(46.7 \%)$ and chronic kidney disease $(43.3 \%)$. In hyponatremic patients, diabetes mellitus and hypertension had the same prevalence ( $25.8 \%$ vs $25 \%$ respectively), while in hypernatremic patients, the most common diseases were hypertension and heart failure/ ischemic heart disease (5.8\% for each).

Table (3) showed that among elderly <80 years, $44.19 \%$ had hyponatremia $(27.91 \%, 12.79 \%, 3.49 \%$ had mild, moderate, severe hyponatremia respectively, while $9.30 \%$ had hypernatremia either mild or moderate $(8.14 \%, 1.16 \%$ respectively). For elderly patients $\geq 80$ years; $38.24 \%$ of them had hyponatremia either mild, moderate, or severe $(14.71 \%, 14.71 \%, 8.82 \%$ respectively), while $14.71 \%$ had hypernatremia either mild or moderate $(5.88 \%, 8.82 \%$ respectively).

Total in-hospital mortality for all ICU patients was $60 \%$. Among non-survivors $45.83 \%$ had hyponatremia $(26.39 \%$, $13.89 \%, 5.56 \%$ had mild, moderate severe hyponatremia respectively) while $9.72 \%$ had hypernatremia $(6.94 \%$, $2.78 \%$ for mild, moderate hypernatremia respectively). 
Table 2: Dysnatremia with comorbidities

\begin{tabular}{|c|c|c|c|c|c|c|c|c|c|}
\hline All ICU patients & & НyІ & atremia & & Normal & & pernatr & & p- \\
\hline$($ total $n=120)$ & $\begin{array}{l}\text { All } \\
51(42.5 \%)\end{array}$ & $\begin{array}{l}\text { Severe } \\
6(6 \%)\end{array}$ & $\begin{array}{l}\text { Moderate } \\
16(13.3 \%)\end{array}$ & $\begin{array}{l}\text { Mild } \\
29(24.2 \%)\end{array}$ & $\begin{array}{l}\text { Normal } \\
56(46.7 \%)\end{array}$ & $\begin{array}{l}\text { All } \\
13(10.8 \%)\end{array}$ & $\begin{array}{l}\text { Mild } \\
9(7.5 \%)\end{array}$ & $\begin{array}{l}\text { Moderate } \\
4(3.3 \%)\end{array}$ & value \\
\hline $\begin{array}{l}\text { Hypertension } \\
\text { n (\%): } \quad 69 \\
(\mathbf{5 7 . 5 \% )}\end{array}$ & $\begin{array}{l}30 \\
(25 \%)\end{array}$ & $\begin{array}{l}4 \\
(3.3 \%)\end{array}$ & $\begin{array}{l}11 \\
(9.2 \%)\end{array}$ & $\begin{array}{l}15 \\
(12.5 \%)\end{array}$ & $\begin{array}{l}32 \\
(26.7 \%)\end{array}$ & $\begin{array}{l}7 \\
(5.8 \%)\end{array}$ & $\begin{array}{l}6 \\
(5 \%)\end{array}$ & $\begin{array}{l}1 \\
(0.8 .0 \%)\end{array}$ & 0.628 \\
\hline $\begin{array}{l}\text { Atrial Fibrillation } \\
\text { n (\%): } \quad 19 \\
(15.8 \%)\end{array}$ & $\begin{array}{l}11 \\
(9.2 \%)\end{array}$ & $\begin{array}{l}0 \\
(0 \%)\end{array}$ & $\begin{array}{l}3 \\
(2.5 \%)\end{array}$ & $\begin{array}{l}8 \\
(6.7 \%)\end{array}$ & $\begin{array}{l}7 \\
(5.8 \%)\end{array}$ & $\begin{array}{l}1 \\
(0.8 \%)\end{array}$ & $\begin{array}{l}1 \\
(0.8 \%)\end{array}$ & $\begin{array}{l}0 \\
(0 \%)\end{array}$ & 0.346 \\
\hline $\begin{array}{l}\text { Heart Failure } \\
\text { n }(\%): \quad 40(33.3 \%)\end{array}$ & $\begin{array}{l}17 \\
(14.17 \%)\end{array}$ & $\begin{array}{l}1 \\
(0.8 \%)\end{array}$ & $\begin{array}{l}8 \\
(6.7 \%)\end{array}$ & $\begin{array}{l}8 \\
(6.7 \%)\end{array}$ & $\begin{array}{l}16 \\
(13.3 \%)\end{array}$ & $\begin{array}{l}7 \\
(5.8 \%)\end{array}$ & $\begin{array}{l}6 \\
(5.0 \%)\end{array}$ & $\begin{array}{l}1 \\
(0.8 \%)\end{array}$ & 0.137 \\
\hline $\begin{array}{l}\text { Stroke } \\
\text { n }(\%):\end{array}$ & $\begin{array}{l}17 \\
(14.17 \%)\end{array}$ & $\begin{array}{l}1 \\
(0.8 \%)\end{array}$ & $\begin{array}{l}8 \\
(6.7 \%)\end{array}$ & $\begin{array}{l}8 \\
(6.7 \%)\end{array}$ & $\begin{array}{l}19 \\
(15.8 \%)\end{array}$ & $\begin{array}{l}6 \\
(5 \%)\end{array}$ & $\begin{array}{l}3 \\
(2.5 \%)\end{array}$ & $\begin{array}{l}3 \\
(2.5 \%)\end{array}$ & 0.304 \\
\hline $\begin{array}{l}\text { Chronic lung disease } \\
\text { (n) \%: } 27 \\
(22.5 \%)\end{array}$ & $\begin{array}{l}7 \\
(5.8 \%)\end{array}$ & $\begin{array}{l}1 \\
(0.8 \%)\end{array}$ & $\begin{array}{l}4 \\
(3.3 \%)\end{array}$ & $\begin{array}{l}2 \\
(1.7 \%)\end{array}$ & $\begin{array}{l}15 \\
(12.5 \%)\end{array}$ & $\begin{array}{l}5 \\
(4.2 \%)\end{array}$ & $\begin{array}{l}3 \\
(2.5 \%)\end{array}$ & $\begin{array}{l}2 \\
(1.7 \%)\end{array}$ & 0.209 \\
\hline $\begin{array}{l}\text { Liver cell failure } \\
\text { n }(\%): \quad 25 \\
(20.8 \%)\end{array}$ & $\begin{array}{l}12 \\
(10 \%)\end{array}$ & $\begin{array}{l}3 \\
(2.5 \%)\end{array}$ & $\begin{array}{l}3 \\
(2.5 \%)\end{array}$ & $\begin{array}{l}6 \\
(5.0 \%)\end{array}$ & $\begin{array}{l}9 \\
(7.5 \%)\end{array}$ & $\begin{array}{l}4 \\
(3.3 \%)\end{array}$ & $\begin{array}{l}3 \\
(2.5 \%)\end{array}$ & $\begin{array}{l}1 \\
(0.8 \%)\end{array}$ & 0.441 \\
\hline $\begin{array}{l}\text { Diabetes } \\
\text { nellitus } \\
(\mathbf{\%}): \quad 56 \\
(46.7 \%)\end{array}$ & $\begin{array}{l}31 \\
(25.8 \%)\end{array}$ & $\begin{array}{l}4 \\
(3.3 \%)\end{array}$ & $\begin{array}{l}12 \\
(10.0 \%)\end{array}$ & $\begin{array}{l}15 \\
(12.5 \%)\end{array}$ & $\begin{array}{l}22 \\
(18.3 \%)\end{array}$ & $\begin{array}{l}3 \\
(2.5 \%)\end{array}$ & $\begin{array}{l}2 \\
(1.7 \%)\end{array}$ & $\begin{array}{l}1 \\
(0.8 \%)\end{array}$ & 0.061 \\
\hline $\begin{array}{l}\text { Chronic Kidney } \\
\text { Disease } \\
\text { n }(\%): \\
(43.3 \%)\end{array}$ & $\begin{array}{l}21 \\
(17.5 \%)\end{array}$ & $\begin{array}{l}3 \\
(2.5 \%)\end{array}$ & $\begin{array}{l}6 \\
(5.0 \%)\end{array}$ & $\begin{array}{l}12 \\
(10.0 \%)\end{array}$ & $\begin{array}{l}26 \\
(21.7 \%)\end{array}$ & $\begin{array}{l}5 \\
(4.2 \%)\end{array}$ & $\begin{array}{l}4 \\
(3.3 \%)\end{array}$ & $\begin{array}{l}1 \\
(0.8 \%)\end{array}$ & 0.950 \\
\hline $\begin{array}{l}\text { Malignancy } \\
\text { n }(\%): \quad 14 \\
(11.7 \%)\end{array}$ & $\begin{array}{l}9 \\
(7.5 \%)\end{array}$ & $\begin{array}{l}2 \\
(1.7 \%)\end{array}$ & $\begin{array}{l}2 \\
(1.7 \%)\end{array}$ & $\begin{array}{l}5 \\
(4.2 \%)\end{array}$ & $\begin{array}{l}5 \\
(4.2 \%)\end{array}$ & $\begin{array}{l}0 \\
(0 \%)\end{array}$ & $\begin{array}{l}0 \\
(0 \%)\end{array}$ & $\begin{array}{l}0 \\
(0 \%)\end{array}$ & 0.332 \\
\hline
\end{tabular}

Table (3): Relation of dysnatremia to age groups and mortality

\begin{tabular}{|c|c|c|c|c|c|c|c|c|c|}
\hline \multirow{2}{*}{$\begin{array}{l}\text { All ICU patients } \\
\text { (total } N=120)\end{array}$} & \multicolumn{4}{|c|}{ Hyponatremia } & \multirow{2}{*}{$\begin{array}{l}\text { Normal } \\
\text { Normal }\end{array}$} & \multicolumn{3}{|c|}{ Hypernatremia } & \multirow{2}{*}{$\begin{array}{l}\text { p- } \\
\text { value }\end{array}$} \\
\hline & All & Severe & Moderate & Mild & & All & Mild & Moderate & \\
\hline $\begin{array}{l}\text { Patients <80 years } \\
\qquad \mathrm{N}=86(71.7 \%)\end{array}$ & $\begin{array}{l}38 \\
(44.19 \%)\end{array}$ & $\begin{array}{l}3 \\
(3.49 \%)\end{array}$ & $\begin{array}{l}11 \\
(12.79 \%)\end{array}$ & $\begin{array}{l}24 \\
(27.91 \%)\end{array}$ & $\begin{array}{l}40 \\
(46.51 \%)\end{array}$ & $\begin{array}{l}8 \\
(9.30 \%)\end{array}$ & $\begin{array}{l}7 \\
(8.14 \%)\end{array}$ & $\begin{array}{l}1 \\
(1.16 \%)\end{array}$ & \multirow{3}{*}{0.175} \\
\hline $\begin{array}{l}\text { Patients } \geq 80 \text { years } \\
\qquad N=34(28.3 \%)\end{array}$ & $\begin{array}{l}13 \\
(38.24 \%)\end{array}$ & $\begin{array}{l}3 \\
(8.82 \%)\end{array}$ & $\begin{array}{l}5 \\
(14.71 \%)\end{array}$ & $\begin{array}{l}5 \\
(14.71 \%)\end{array}$ & $\begin{array}{l}16 \\
(47.06 \%)\end{array}$ & $\begin{array}{l}5 \\
(14.71 \%)\end{array}$ & $\begin{array}{l}2 \\
(5.88 \%)\end{array}$ & $\begin{array}{l}3 \\
(8.82 \%)\end{array}$ & \\
\hline $\begin{array}{l}\text { Survivor } \\
\qquad N=48(40.0 \%)\end{array}$ & $\begin{array}{l}18 \\
(37.5 \%)\end{array}$ & $\begin{array}{l}2 \\
(4.17 \%)\end{array}$ & $\begin{array}{l}6 \\
(12.5 \%)\end{array}$ & $\begin{array}{l}10 \\
(20.83 \%)\end{array}$ & $\begin{array}{l}24 \\
(50 \%)\end{array}$ & $\begin{array}{l}6 \\
(12.5 \%)\end{array}$ & $\begin{array}{l}4 \\
(8.33 \%)\end{array}$ & $\begin{array}{l}2 \\
(4.17 \%)\end{array}$ & \\
\hline $\begin{array}{l}\text { Non-survivor } \\
\qquad N=72(60.0 \%)\end{array}$ & $\begin{array}{l}33 \\
(45.83 \%)\end{array}$ & $\begin{array}{l}4 \\
(5.56 \%)\end{array}$ & $\begin{array}{l}10 \\
(13.89 \%)\end{array}$ & $\begin{array}{l}19 \\
(26.39 \%)\end{array}$ & $\begin{array}{l}32 \\
(44.44 \%)\end{array}$ & $\begin{array}{l}7 \\
(9.72 \%)\end{array}$ & $\begin{array}{l}5 \\
(6.94 \%)\end{array}$ & $\begin{array}{l}2 \\
(2.78 \%)\end{array}$ & 0.966 \\
\hline
\end{tabular}




\section{Discussion}

The current study done to assess prevalence of dysnatremia in elderly ICU patients, and any association between dysnatremia with its grades and inhospital ICU mortality. In our work we found that, hyponatremia was found in $42.5 \%$ of all ICU patients, while hypernatremia was found in $10.83 \%$ of all ICU patients. This prevalence agreed with the study done by Darmon et al, 2013 [21] who found that one-third of critically ill ICU patients had a moderate to severe dysnatremia. Also, the severity of hyponatremia in our study was found as Mild (24.2\%), moderate (13.3\%), and severe hyponatremia $(6 \%)$ which are similar with results of Darmon et al., 2013 [21] who found that $18.02 \%$ had mild hyponatremia, $6.23 \%$ had moderate hyponatremia, $3.14 \%$ had severe hyponatremia.

Regarding prevalence of hypernatremia, we found hypernatremia with its degrees as mild, moderate, or severe hypernatremia were $(7.5 \%, 3.3 \%, 0 \%$ respectively), which is also in agreement with Darmon et al., 2013 [21] who found that $5.69 \%$ had mild hypernatremia, $1.29 \%$ had moderate hypernatremia, and $0.91 \%$ had severe hypernatremia, as well as in agreement with a study by Lindner et al., 2007 [3] which found the prevalence of hypernatremia in ICU to be $9 \%$. Hypernatraemia seems to be caused in the ICU because of renal water loss, which is then corrected with too little water or overcorrection with hypertonic fluids. Therefore therapy should depend on adding electrolyte-free water and/or creating a negative sodium balance [9].

The current study found that hyponatremia was more prevalent in certain medical conditions as in diabetes mellitus (25.8\%), heart failure (14.17) and liver cell failure (10\%). that is in accordance with the findings of other studies as Adrogué et al, 2000 [7] who found that hyponatremia is a consequence of chronic organ dysfunctions as heart failure or liver cirrhosis.

We studied the association, if any, between dysnatremia and ICU mortality, and we found that hyponatremia was found more among non-survivors compared to survivors ( $45.83 \%$ vs $37.5 \%$ respectively), although this difference was not statistically significant. But this may be attributed to our small sample size. The increased mortality among hyponatremic patients is supported by previous studies by Funk et al, 2010 [2] and Hoorn et al., 2013 [22] that concluded that hyponatremia is an independent risk factor for poor prognosis. We did not find any association between hypernatremia and in-hospital ICU mortality.

Conclusion: Dysnatremia's prevalence is high in geriatric elderly patients, hyponatremia is more frequent than hypernatremia. Mild form of dysnatremia is the most prevalent type in both groups.

\section{References}

1] Bennani SL, Abouqal R, Zeggwagh AA, et al (2003): Incidence, causes and prognostic factors of hyponatremia in intensive care. Rev Med Interne, 24, 224-229.

2] Funk GC, Lindner G, Druml W, et al. (2010): Incidence and prognosis of dysnatremias present on ICU admission. Intensive Care Med. 36(2), 30411.

3] Lindner G, Funk GC, Schwarz C, et al (2007): Hypernatremia in the critically ill is an independent risk factor for mortality. Am J Kidney Dis., 50, 952-957.

4] Sedlacek M, Schoolwerth AC, and Remillard BD (2006): Electrolyte disturbances in the intensive care unit. Semin Dial, 19, 496-501.

5] Zilberberg MD, Exuzides A, Spalding J, et al (2008): Epidemiology, clinical and economic outcomes of admission hyponatremia among hospitalized patients. Curr Med Res Opin, 24,1601-1608

6] Kumar S and Berl T (1998): Sodium. Lancet., 352(9123), 220-8.

7] Adrogué HJ, and Madias NE (2000): Hyponatremia. N Engl J Med, 342, 1581-1589.

8] Hoorn, E.J., Lindemans, J., and Zietse, R. (2006): Development of severe hyponatraemia in hospitalized patients: treatment-related risk factors and inadequate management. Nephrol Dial Transplant., 21, 70-6.

9] Hoorn EJ, Betjes MGH, Weigel J, et al (2008): Hypernatraemia in critically ill patients: too little water and too much salt. Nephrol Dial Transplant, 23, 1562-1568

10] Polderman KH, Schreuder WO, Strack van Schijndel RJ, et al (1999): Hypernatremia in the intensive care unit: an indicator of quality of care? Crit Care Med. ;27(6):1105-1108.

11] Macdonald NJ, McConnell KN, Stephen MR, et al (1989) :Hypernatraemic dehydration in patients in a large hospital for the mentally handicapped. BMJ, 299, 1426-1429.

12] Palevsky PM, Bhagrath $R$, and Greenberg $A$ (1996): Hypernatremia in hospitalized patients. Ann Intern Med, 124, 197-203.

13] Long CA, Marin P, Bayer AJ, et al (1991): Hypernatraemia in an adult in-patient population. Postgrad Med J, 67, 643-645.

14] Borra SI, Beredo R, and Kleinfeld M (1995): Hypernatremia in the aging: causes, manifestations, and outcome. J Natl Med Assoc, 87,220 224.

15] Bratusch-Marrain PR, and DeFronzo RA (1983): Impairment of insulinmediated glucose metabolism by hyperosmolality in man. Diabetes, 32,1028-1034.

16] Lenz K, Gossinger H, Laggner A, et al (1986): Influence of hypernatremic hyperosmolar state on hemodynamics of patients with normal and depressed myocardial function. Crit Care Med, 14, 913-914.

17] Druml W, Kleinberger G, Lenz K, et al (1986): Fructose-induced hyperlactemia in hyperosmolar syndromes. Klin Wochenschr, 64, 615-618. 18] Kozeny GA, Murdock DK, Euler DE, et al (1985): In vivo effects of acute changes in osmolality and sodium concentration on myocardial contractility. Am Heart J, 109, 290-296.

19] Knochel JP (1982): Neuromuscular manifestations of electrolyte disorders. Am J Med, 72,521-535.

20] Adrogue H J, and Madias NE (2000): Hypernatremia. N Engl J Med, 342,1493-1499.

21] Darmon M, Diconne E, Souweine B, et al (2013): Prognostic consequences of borderline dysnatremia: pay attention to minimal serum sodium change. Critical Care, 17, R12.

22] Hoorn EJ and Zietse R (2013): Hyponatremia and mortality: moving beyond associations. Am J Kidney Dis; 62 (1):139-149. 